\title{
A Cognitive Approach to EkeGusii Pop Songs
}

\author{
Victor Ondara Ntabo ${ }^{*}$, Moses Gatambuki Gathigia ${ }^{2}$, Naom Moraa Nyarigoti ${ }^{2}$ \\ ${ }^{1}$ Department of Languages, Karatina University, Kenya, P.O. Box 96046-80110, Likoni, Mombasa, Kenya \\ ${ }^{2}$ Department of Languages, Karatina University, Kenya, P.O. Box 1957-10101 or 540-10101, Karatina, Kenya
}

Corresponding Author: Victor Ondara Ntabo, E-mail: ntabovictor@gmail.com

\section{ARTICLE INFO}

Article history

Received: March 18, 2018

Accepted: May 09, 2018

Published: June 30, 2018

Volume: 9 Issue: 3

Advance access: May 2018

Conflicts of interest: None

Funding: None

\author{
Key words: \\ Amasomo, \\ CMT, \\ Great Chain of Being Metaphor, \\ MIPVU, \\ Pop Songs,
}

\begin{abstract}
A review of literature on pop songs reveals that composers use metaphors to communicate their feelings. In particular, the meaning of the metaphors in EkeGusii pop songs needs to be interpreted to reveal the message of the composers. The EkeGusii pop singer Christopher Mosioma's (Embarambamba) songs have gained fame in Kenya because of their richness in the usage of metaphors. One of Christopher Mosioma's songs, amasomo (education) which was launched in 2015 has gained acclaim from Kenyans. The song amasomo (education) is basically presented as a piece of advice to students to embrace education in order to optimally reap from its benefits. The study identified 10 metaphors in the song amasomo (education) through the Metaphor Identification Procedure Vrije Universiteit. In order to interpret the metaphors in the EkeGusii pop song amasomo (education), the Conceptual Metaphor Theory complemented by the folk conception of the generic Great Chain of Being Metaphor were employed. The study employed four coders (including the researchers) in the identification of the metaphors. The study found that, inter alia, animal, plant and object metaphors are used in the song amasomo (education). The study concludes that the metaphors in the EkeGusii pop songs belong inherently to different levels of the generic Great Chain of Being Metaphor.
\end{abstract}

\section{INTRODUCTION}

Pop songs express social messages that can be traced to a conscious communicative effort of the composer (Bikknell, 2002). Bikknell further notes that pop songs are often emotional and they mostly relay issues related to love. The composers use metaphors to express poetic ideas and subjective emotional states through purely musical means (Scruton, 2005). The meaning of the metaphors in the EPS amasomo (education) needs to be objectively revealed to comprehend the message of the composer. The aim of the paper, therefore, is to interpret the metaphors in EkeGusii pop songs (EPS) using the Conceptual Metaphor Theory.

The term "pop song" was first recorded as being used in 1926 in the sense of music with a popular appeal (Hatch \& Milward, 1987). The following famous pop song singers and music groups have been recorded in history: Crooners of the 1930s and 1940s, Beetles of the 1960s, the American Back street Boys of the 1980s and 1990s, and Britney Spears and Mariah Carey of the late 1990s and early 2000 (Simon \& Will, 2004). According to Sullivan (2013), pop songs have the following basic characteristics: first, the songs aim at mass audience; second, the style changes significantly depending on the time and place to gain favour with many people; and lastly, pop songs have danceable rhythm, simple melodies, memorable and repetitive structures. The pop music includes the subgenres of rock, jazz, rhythm and blues, and some folk songs (Simon \& Will, 2001).

EkeGusii artists have composed pop songs that convey messages on concepts of love, marriage relationships and education in different perspectives. Christopher Mosioma, for instance, whose stage name is Embarambamba, composed and sang the EkeGusii pop song amasomo (education), which has gained appeal because of the metaphorical language used. Embarambamba's song amasomo (education) was released in 2015. The song underscores the value of education and offers pieces of advice to the youth to embrace education to reap its benefits. Embarambamba's other songs include: Amatindogoro, E'weekend and Zipporah. This study interprets the metaphors in Embarambamba's EPS amasomo (education) in order to understand the EkeGusii culture and metaphoricity.

The paper is based on Cognitive Semantics which is a branch of Cognitive Linguistics. Cognitive Linguistics is an interdisciplinary approach to language that posits that there is a nexus among language, the mind and socio-cultural experience (Evans \& Green, 2006). Cognitive Linguistics is viewed as a cognitive function as opposed to formal approaches to language (Finch, 2000). Palinkas (2006), 
for example, postulates that Cognitive Linguistics was developed as a protest to the formal approaches to linguistics which treated metaphor, analogy and metonymy as deviant linguistic phenomena. Cognitive Semantics provides that meanings are represented in peoples' mind in a configuration that has its unique rules (Croft \& Cruse, 2004). Finch (2000) argues that Cognitive Semantics describes the semantic approaches to language that sees no separation between linguistic knowledge and general thinking or cognition. Cognitive Semantics, therefore, adopts a functional view of language as opposed to formal approaches of language. In addition, Cognitive Semantics provides that the meaning of words and other linguistic units are inseparably related to the hearer's memory and experience (Evans \& Green, 2006). Meaning, thus, is not located in the actual world but in our heads.

In the realm of Cognitive Linguistics, metaphors are devices that enable people to comprehend one domain of experience in terms of another (Lakoff \& Johnson, 1980). Lakoff (2008) defines a metaphor ${ }^{1}$ as a tool that helps make sense of abstract notions through concrete ones. Metaphors not only play a role in human thought, understanding and reasoning but also aid in the creation of people's social, cultural, and psychological reality (Lakoff \& Johnson, 1980). They, therefore, are primarily conceptual, universal and conventionally part of ordinary system of thought. Wheeler (1994) posits that metaphor is not only a specific figure of speech, but it is also the foundation of language. Lakoff and Johnson (1980) point out that our conceptual system, in terms of the way we both think and act is basically metaphoric in nature. In other words, language is indeed hardly metaphor free (Deignan, 2005). This study, therefore, interprets the metaphors in the EkeGusii pop song amasomo (education) to reveal the meaning of the metaphors employed ${ }^{2}$.

The conceptualization of metaphors can be interpreted within the generic Great Chain of Being Metaphor (GCBM) (Kövecses, 2002). The main feature of the GCBM is that all existing things in the universe have their positions in a divinely planned order. Kövecses (2002) further points out that the hierarchy is considered to be a vertical chain in which different things occupy their corresponding places on the basis of their characteristics. The highest level is normally occupied by God, followed by the Universe, Society, People, Fauna, Flora, Objects and Physical Things in that order (Kövecses, 2002). According to Krzeszowski (1997), each level is described by specific attributes that can be metaphorically inherited. The GCBM is, thus, employed to comprehend the metaphors in Christopher Mosioma's (Embarambamba) EkeGusii pop song amasomo (education).

\section{THEORETICAL FRAMEWORK}

The paper adopted the Conceptual Metaphor Theory (CMT). The CMT, which was propounded by Lakoff and Johnson (1980) is a commonly used cognitive model in Cognitive Linguistics. The CMT defines a metaphor as a cross domain mapping in the conceptual system which includes a conceptual correspondence from a source domain (SD) to the target domain (TD). The SD includes what is physical or more concrete while TD includes what is abstract (Lakoff, 1993). According to Ahrens (2002), the concrete domain is referred to as the source while the abstract is the target. The study employed the CMT to evaluate the mappings of the source domains which are physical to abstract domains which are mental concepts to reveal meaning. The meaning of metaphors, therefore, is a result of the conceptual mappings. This validates Cameron and Low's (1999) assertion that metaphor is a matter of the mind. The CMT uses capitalized mnemonics along the line of "TARGET DOMAIN IS/ AS SOURCE DOMAIN." Metaphors are mapped from the concrete source domain to the abstract target domain in the conceptual system using the copula (IS) or (AS). This study found the CMT applicable since it was employed to analyze the metaphors in EkeGusii pop songs (EPS). The CMT was used in studying the mapping of the SD to the TD to identify the underlying meaning of the metaphors in the EPS. In order to interpret the metaphors in the EkeGusii pop song amasomo (education), the CMT was complemented in this study by the generic Great Chain of Being Metaphor. The GCBM was used because it normally guides in the conceptualization of metaphors (Kövecses, 2002). The GCBM also stresses on the interrelations between animate and inanimate entities which form a constituent chain link (Laura, 2004).

\section{METHODOLOGY OF THE STUDY}

The study involved a qualitative analysis of the metaphors in the EkeGusii pop song amasomo (education) by Embarambamba. The song amasomo (education) ${ }^{2}$ was considered for study since it is rich in metaphors based on the Metaphor Identification Procedure Vrije Universiteit (MIPVU) ${ }^{1}$. Creswell (2007) notes that a qualitative research reveals the way things are by educating the reader about phenomena as experienced by the study participants and interpreted by the researcher in a relevant context. The research also used four coders (including the researchers) to indentify the metaphors from the song using the MIPVU. The coders classified words as metaphors based on Steen's et al (2010) provision that words are identified as metaphors if they are indirectly used and may potentially be explained by some form of cross domain mapping from a more basic meaning of the words. An inter rater reliability test was used to enhance precision in the identification of metaphors. Cameron's (2003) argument that a word which attains at least $75 \%$ in the inter-rater reliability test is marked a metaphor was considered. Each coder, therefore, assigned 0.25 to the words considered a metaphor. Once at least three coders were in agreement that the word is a metaphor, 0.25 was multiplied by 3 to obtain 0.75 which is $75 \%$. All the four coders were in unanimous agreement that the 10 instantiations identified in this study were metaphorical. The principle of the Great Chain of Being Metaphor (GCBM) (Kövecses, 2002) was further employed to classify the identified metaphors into the conceptual domains of: animal, plant and object. Content analysis was also adopted to guide in the analysis of the metaphors in Embarambamba's song. The identified metaphors were presented in a table which highlighted the metaphors and their conceptual domains. 


\section{FINDINGS AND DISCUSSION}

The study classified the identified metaphors into three chains using the folk conception of the generic Great Chain of Being Metaphor (GCBM). Each chain is distinguished by particular attributes and behavior. Krzeszowski (1997) argues that each chain is defined by specific attributes, which, however, can be metaphorically inherited. The chains in the EkeGusii pop songs that were identified include: animal, plant and object. Table 1 below highlights the animal, plant and object metaphors in the EPS amasomo (education) and their level in the generic GCBM.

\section{Animal Metaphor}

The animal chain occupies a pleasant position in the folk conception of the GCBM. It is, therefore, common to compare a human being with an animal based on human-animal interactions. Feinstein (2015) posits that the human-animal interactions are based on the biophila hypothesis which provides that an emotional and beneficial relationship exists between humans and nature in which there is an innate tendency to focus on life and life like processes. There are, thus, shared dynamic associations between human beings and animals. Rearing of goats for instance, is considered beneficial since it has a nutritional gain through goat products like milk. Conceptualizing a human being as a goat is, therefore, common. Embarambamba for example compares a human being with a goat as in metaphor (1) below:

(1) Omonto n' embori -'a human being is a goat'.

Embarambamba, in the EkeGusii pop song (EPS) amaso$m o$ (education) sings that a human being who embraces education is embori (a goat). Goats are useful animals since they produce milk, meat, hair and skins and are easy to tame. In instantiation (1) above, omonto (a human being) is the Target Domain (TD) while embori (goat) is the Source Domain (SD) based on the tenets of the Conceptual Metaphor Theory (CMT) by Lakoff and Johnson (1980). Therefore, one of the corresponding conceptual mappings of the TD corresponding to the SD is: physical satisfaction corresponding to perception. Embori (goat) is food that can be eaten to physically satisfy someone, thus, it can be compared to a scholar's academic appetite. The singer employs (1) above to give a piece of advice to students to embrace education to attain its benefits. This suggests that amasomo (education) is a beneficial thing for human beings just like embori (a goat).

\section{Plant Metaphors}

The Great Chain of Being metaphor (GCBM) was also used to conceptualize human beings and the concept of education using plants. Lakoff and Turner (1989) argue that the GCBM is a tool of great power and scope as it allows people to understand general human behavior. López (2009) provides that when people are compared with plants, they are usually demeaned. In this study, Embarambamba has used plant metaphors to describe human beings and the concept of education. Rosinska (2016) notes that speakers have coined plants related lexemes to comprehend and also represent human beings. For example, the terms bud and weed are employed by Rosinska (2016) to represent human behaviorr in Polish. Ronsiska further posits that plants are well represented in cognitive storage structures for instance in categories, frames or idealized cognitive models. According to Kleparski (2008), plants are intermittently used to conjure up phenomena.

Ebinagwa (the Mauritius thorns) metaphor (2) below, for example, is used to depict the qualities students need to have to acquire education. Ebinagwa (Mauritius thorns) is both used as a hedge plant to secure homes and organizations against unauthorized entry and also as a weapon because the plant has sharp thorns that can be used to repulse perceived enemies as the thorns pierce the intruders. Thus:

(2) Amasomo n' ebinagwa -'education is Mauritius thorns'.

Ebinagwa (Mauritius thorns), whose botanical name is caesaipinia decapetala is an aggressive exotic plant which was initially imported to Africa as a hedge plant. Ebinagwa (Mauritius thorns) are evergreen, scrambling woody shrubs with very sharp prickles which originated in India. Ebinagwa (Mauritius thorns) is the SD while Amasomo (Education) which Lydia, a character in the song who is advised to imbibe education is the TD. Metaphor (2) reveals that the acquisition of education is challenging, tormenting, devastating and harmful like Ebinagwa (Mauritius thorns) and students need

Table 1. Animal, plant and object metaphors in amasomo (education) EkeGusii pop song

\begin{tabular}{llll}
\hline No & EkeGusii & Gloss & Conceptual domain \\
\hline 1 & Omonto n'embori & A human being is a goat & ANIMAL \\
2 & Amasomo n'ebinagwa & Education is mauritius thorns & PLANT \\
3 & Omonto n' rinani & A human being is a forest & PLANT \\
4 & Amasomo n'endagera & Education is food & OBJECT \\
5 & Omonto n'amabuta & A human being is oil & OBJECT \\
6 & Omonto n'MPESA & A human being is mobile money & OBJECT \\
7 & Omonto n'egetenge & A human being is a kitenge & OBJECT \\
8 & Omonto n'ekebeya & A human being is a tin lamp & OBJECT \\
9 & Omonto n'ekanisa & A human being is a church & OBJECT \\
10 & Omonto n'ekeragita & A human being is a tractor & OBJECT \\
\hline
\end{tabular}


to endure the hardships associated with the acquisition of education to gain from it. Metaphor (2) above also depicts the misery, pain, disappointment and disagreeable experiences of life characterized with people who have not fully embraced education. Embarambamba, therefore, prevails on students to embrace education to reap its benefits. This is because education, according to Pallais (2014), enables people to acquire skills, techniques and attitudes to guarantee quality living.

Metaphors (3) below is also used to conceptualize a human being.

(3) Omonto n'rinani -'a human being is a forest'.

In the EkeGusii pop song amasomo (education), a human being is negatively conceptualized as rinani (forest). A forest is normally a large area dominated with different species of trees. According to Manaseh (2016), effective learning which culminates to acquisition of quality education should subscribe to the educational principle which requires a student to be objective, organized, goal oriented and to prepare to acquire the educational concepts one at a time. Metaphor (3) is appropriately employed to depict a student who lacks objectivity, organization, clear goals and is unable to acquire the educational concepts one at a time. A learner who does not comply with the education principle is apparently the one whom Embarambamba negatively conceptualizes as rinani (a forest) in the EPS amasomo (education).

\section{Object Metaphors}

López (2009) posits that the process of comparing people with objects invokes the feelings of love and abhorrence depending on the things involved. Metaphors (4 -10) in Table 4.1 highlight the conceptual metaphor EDUCATION IS AN OBJECT in Embarambamba's EkeGusii pop song amasomo (education). Therefore:

(4) Amasomo n'endagera -'education is food'.

Kövecses (1986) posits that food is something edible and indispensable for human beings. The indispensability of food is compared with amasomo (education) as highlighted in (4) above. Emasomo (education) is seen as an object of consumption that a human being cannot do without. In (4) above, Embarambamba positively conceptualizes amasomo (education) as endagera (food) in the EPS song amasomo (education). Food is what is eaten to keep animals and human beings healthy, strong and free from diseases (Allen, 2017). Metaphor (4) above also has a biblical interpretation. In Matthew 4:1-11, the temptation of Christ by the devil is described. Jesus is put into test by the devil after spending forty days and nights without eating. The devil asks Christ to turn stones into bread but Jesus answers that man need not to live on bread alone but by every word which comes from the mouth of God (The Holy Bible, 1982).The word that comes from the mouth of God is tantamount to endagera (food) which is comparable with amasomo (education) as given by God to guide people to morality. In line with (4) above, amasomo (education) is endagera (food) which is indispensable for human beings.
Metaphor (5) below is employed by Embarambamba in the EPS amasomo (education) to positively conceptualize scholars. An educated person is depicted as an attractive person. Therefore:

(5) Omonto n'amabuta -'a human being is oil'.

Beauty is an attractive appearance which normally draws peoples' admiration (Rhodes, 2010). Human beings apply oil skins to keep their skin hydrated which protects the skin from drying up and making it smooth and oily (Eleanor, 2006). Eleanor further notes that human beings acquire a positive self image and an implicit self-esteem by making oneself attractive through applying oil skins. Embarambamba sings that omwana osomete (an educated child) is amabuta (oil) in the EPS amasomo (education). Embarambamba correlates education with oil skins to insinuate that scholars are admirable people in society.

In metaphor (6), a human being is conceptualized as MPESA. MPESA is a mobile money transfer service which is associated with Safaricom, a leading mobile phone company in Kenya (Morawczynski, 2010). Therefore:

(6) Omonto n'MPESA -'a human being is mobile money'.

MPESA mainly offers a short message-based money transfer system that allows individuals to deposit, send and withdraw funds using their cell phone (Jack \& Suri, 2010). Safaricom deals in cellular communication, internet, money transfer and payment services. MPESA is synonymously used with money in Kenya because it is the largest and commonly used mobile money transfer service in Kenya (Jack \& Suri, 2010). A human being who is endowed with sufficient money enjoys a high social class status as money is viewed as a measure of wealth (Jenkins, 2011). Embarambamba compares Daudi (David), a character in the EPS amasomo (education) with MPESA. In this case, Daudi (David) is the Target Domain (TD) while MPESA which is synonymous with money in Kenya (Jack \& Suri, 2010), is the Source Domain (SD). One of the corresponding conceptual mappings of the TD corresponding with the SD is: perception corresponds to physical appearance. This suggests that since Daudi (David) is not only an educated person but he is also wealthy. Money can also be compared with education because both are considered promising things obtained after hard work.

The egetenge (kitenge) metaphor is also used to conceptualize a human being. Egetenge (kitenge) is a colourful Swahili dress which is normally worn by women during social functions like: weddings, funerals or communal parties (Khamis, 2005). Therefore:

(7) Omonto n' egetenge -'a human being is a kitenge'.

In (7) above, Embarambamba implores Pamela, a character in the EPS amasomo (education) who is compared with egetenge (kitenge) to study. Egetenge (kitenge) is adored for its colourful decorations and patterns (Khamis, 2005). In metaphor (7) above, Pamela is the TD while egetenge (kitenge) is the SD. In this case, the conceptual correspondence between TD corresponding with SD is physical appearance against perception. Embarambamba, therefore, gives a connotation that Pamela is an attractive person but still encourages her to embrace education. This suggests that 
education is normally considered to be more valuable than beauty.

A human being is also conceptualized as ekebeya (a tin lamp) as in metaphor (8) below. A tin lamp is used with a negative undertone to conceptualize a lighting system with inadequate light and characterized with smoke. Ekebeya (a tin lamp) is predominantly used as a source of light in the rural areas of Gusii land (Akama \& Maxon, 2006) where electricity connectivity is either inadequate or the ability to own sophisticated lamps like lanterns and pressure lamps is beyond the reach of the rural dwellers. The use of ekebeya (a tin lamp) is, therefore, associated with poverty. Thus:

(8) Omonto n'ekebeya -'a human being is a tin lamp'.

In metaphor (8) above, Embarambamba conceptualizes Fred, a character in the EPS amasomo (education) as ekebeya (a tin lamp). A tin lamp uses paraffin (kerosene) as a source of fuel. A wick or a mantle which is characterized with smoke is a source of lighting for ekebeya (a tin lamp). In (8) above, ekebeya (a tin lamp) is the SD while Fred is the TD as per the Conceptual Metaphor Theory (CMT). Since the light produced by ekebeya (a tin lamp) is inadequate and unclean as the lamp is characterized with smoke, Embarambamba insinuates that Fred is inadequate in terms of amasomo (education) and, therefore, beseeches him to embrace amasomo (education).

The church metaphor (9) below is used in the EPS amaso$m o$ (education) to appreciatively conceptualize a scholar. In 1John 4: 8, Christ teaches about the value of love for God and humanity which is the embodiment of the church (The Holy Bible, 1982). Embarambamba draws parallels between a scholar and Christ's teachings on the church. Thus:

(9) Omonto n' ekanisa -'a human being is a church'.

Embarambamba compliments a scholar in the EPS amasomo (education) by referring to him as omonyakanisa (a church). According to Romans 5: 12-21 and 1 Corinthians 15: 45-49, a church is a new humanity where Christ is depicted as a new human being who made redemption for all human beings (The Holy Bible, 1982). The New Testament, therefore, depicts saved persons as renewed human beings in Christ by spirit which is described as the church (Franklin, 2011). Franklin further argues that the introduction of formal education in Africa, which was viewed as a new awakening for Africans, was a great blessing for Africa. In (9) above, Embarambamba positively conceptualizes a scholar as a saved person who is redeemed from bondage by education.

Vehicles are also employed as source domains to conceptualize human beings in the EkeGusii pop song amasomo (education). The comparison between human beings and vehicle metaphors transmits positive connotations. For example, the vehicle metaphor (10) below, in the EPS amasomo (education) is based on mechanical power and strength. Therefore:

(10) Omonto n' ekeragita -'a human being is a tractor'.

In metaphor (10) above, Embarambamba positively conceptualizes a human being as ekeragita (a tractor). Spivy (2007) postulates that a tractor is a large vehicle that is used especially for pulling farm implements or machinery and has a powerful gasoline or diesel motor and large, heavily treaded rear tires. A tractor normally has the capacity to deliver a high tractive effort since it has a powerful engine. In (10) above, omonto (a human being) is the TD while ekeragita (a tractor) is the SD as per the Conceptual Metaphor Theory (CMT). Embarambamba insinuates that an educated person is comparable with the power of a tractor. A tractor which is a type of a vehicle is also considered valuable in society. Armi (2006) argues that human beings normally adore vehicles because vehicles have proved to be an enormous economic boost and uplift for human beings in the society. Embarambamba, therefore, uses metaphor (10) above to prevail on people to acquire amasomo (education).

\section{CONCLUSIONS AND RECOMMENDATIONS}

The study sought to analyze the metaphors in the EkeGusii pop song amasomo (education) using the Conceptual Metaphor Theory (CMT). First, the CMT propounded by Lakoff and Johnson (1980) aided the comprehension of the metaphors in the EPS amasomo (education) by studying the conceptual mappings between the source domain (SD) corresponding to the target domain (TD). The meaning of the metaphors in the EPS amasomo (education) which may have been elusive to the audience of the song amasomo (education) was, therefore, revealed. Second, the conceptual metaphors are vital tools of communication and should be explained using a cognitive semantic approach. Third, the study also concludes that the generic GCBM is essential in understanding the animal, plant and object metaphors in the EPS song amasomo (education).

The paper recommends that for a better understanding of conceptual metaphors, the use of the Conceptual Metaphor Theory (CMT) should be considered to aid in understanding the metaphors in songs. In addition, the folk conception of the Great Chain of Being Metaphor (GCBM) should be employed to classify and analyze the metaphors in accordance with the hierarchical order which exists in the universe. Finally, an inter-rater reliability measure as suggested by Cameron (2003) should be employed to identify metaphors to be considered for analysis in songs.

\section{END NOTES}

1. The term metaphor comes from the two Latin words meta which implies over or across and pherein that stands for to transfer or to carry beyond (Glucksberg, 2001). Metaphor refers to transfer or carry over the attributes one thing or person to another.

2. EkeGusii is a Bantu language spoken by AbaGusii in Kisii and Nyamira Counties in Kenya (Aunga, 2011). EkeGusii is classified as E42 by Guthrie (1971), who further categorizes it in under zone E40.

3. The song amasomo (education) was transcribed and translated to English to ensure accuracy in the identification of metaphors. 
4. The MIPVU was developed by metaphor scholars at Vrije University, Amsterdam as a method of metaphor identification (Steen et al., 2010).

\section{REFERENCES}

Ahrens, K. (2002). When love is not digested: Underlying reasons for source to target domain pairings in the contemporary theory of metaphor. Proceedings of the First Cognitive Linguistics Conference (pp. 273-302). ChengChi University, China.

Akama, J. S., \& Maxon, M. (Eds) (2006). Ethnography of the Gusii of Western Kenya: A vanishing cultural heritage. New York: The Edwin Mellen Press.

Aunga, S. (2011). The nature of homonymous and polysemous relations in EkeGusii (Unpublished MA thesis), Kenyatta University, Kenya.

Allen, S. R. (2017). Food science education and websites. Journal of Food Science Education, 16 (1), 4-5.

Armi, E. (2006). The art of American automobile design. Pennsylvania: Pennsylvania University Press.

Bicknell, J. (2002). Can music convey semantic content? A Kantian approach. The Journal of Aesthetics and Art Criticism, 60 (3), 253-261.

Cameron, L., \& Low, G. (1999). Metaphor. Language Teaching, 32, 77-96.

Cameron, L. (2003). Metaphor in educational discourse. London: Continuum.

Croft, W., \& Cruse, D. (2004). Cognitive Linguistics. Cambridge: Cambridge University Press.

Creswell, J. W. (2007). Qualitative inquiry and research design: Choosing among the five traditions (3rd ed.). California: Thousand Oaks.

Deignan, A. (2005). Metaphor and corpus linguistics. Amsterdam: John Benjamins.

De Nora, T. (2001). Aesthetic agency and musical practice: New directions in the sociology of music and emotion. In J.A. Sloboda and P. Juslin (Eds.), Music and emotion: Theory and research (pp.161-180). Oxford: Oxford University Press.

Eleanor, A. C. (2006). The impact of idealized images of female beauty of women's self concept: Who does it affect and when? (Unpublished doctoral dissertation), University of Massachusetts, USA.

Glucksberg, S. (2001). Understanding figurative language: From metaphor to idiom. Oxford: Oxford University Press.

Guthrie, M. (1971). Comparative Bantu: An introduction to the Comparative Linguistics pre-history of Bantu languages. Farnborough: Gregg press.

Evans, V., \& Green, M. (2006). Cognitive semantics: An introduction. Edinburg: Edinburg University Press.

Feinstein, J. (2015). Examining the effects of human-animal interaction on individuals with developmental disabilities (Unpublished MA thesis), Virginia Commonwealth University, USA.

Finch, G. (2000). Linguistic terms and concepts. New York: Palgrave.
Franklin, S. P. (2011). Being human, being church: The significance of the theological anthropology for ecclesiology (Unpublished doctoral dissertation), McMaster Divinity College, USA.

Hatch, D., \& Milwad, S. (1987). From blues to rock. Manchester: Manchester University Press.

Jack, W., \& Suri, T. (2010). The economics of M-PESA. Innovations, 4 (2), 4-20.

Jenkins, S. (2011). Changing fortunes: Income mobility and poverty dynamics in Britain. Oxford: Oxford University Press.

Jones, A. (2006). Violence and "othering" in colonial and post colonial Africa. Case study: Banda's Malawi. Journal of African Cultural Studies, 18 (2), 197-213.

Khamis, S. A. (2005). Clash of interests and conceptualization of Taarab in East Africa, Swahili Form, 12, 133-159.

Kleparski, G.A. (2008). The joys and sorrows of metaphorical consumption: Mozarellas, prostisciuttos, muttons and yum-yum girls - foodsemy with a romance accent, Z e s z y ty n a u k owe Uniwersyteturzeszowskiego, Seria Filologiczna Studiaanglicare Soviensia, 5, 45-59.

Kövecses, Z. (1986). Metaphor of anger, pride and love: A lexical approach to the structure of concepts. Amsterdam: John Benjamins.

Kövecses, Z. (2002) Metaphor: A practical introduction. Oxford: Oxford University Press.

Krzeszowski, T. P. (1997). Angels and devils in Hell: Elements of axiology in semantics. Warszawa: Wydawnic two Energeia.

Lakoff, G. (1993). The contemporary theory of metaphor. In A. Ortony (Ed.), Metaphor and thought (pp. 202-251). Cambridge: Cambridge University Press.

Lakoff, G., \& Johnson, M. (1980). Metaphors we live by. Chicago: University of Chocago Press.

Lakoff, G. (2008). The neural theory of metaphor. In R.W. Gibbs, Jr (Ed.). The Cambridge handbook of metaphor and thought (pp. 17-38). Cambridge: Cambridge University Press.

Lakoff, G., \& Turner, M. (1989). More than cool reason. A field guide to poetic metaphor. Chicago: University of Chicago Press.

Laura, A. J. (2004). A metaphor is in search of a source domain. The categories of Slavic aspect. Cognitive Linguistics, 15, 171-527.

López, I. (2009). Of women, bitches, chickens and vixens: animal metaphors for women in English and Spanish. Cultura, Lenguaje y Representación/Culture, Language and Representation, 7 (7), 77-100.

Manaseh, A.M. (2016). Instructional leadership: The role of heads of schools in managing the instructional programme. International Journal of Educational Leadership and Management, 4 (1), 30-47.

McDonald, R. (2002). What are musical identities, and why are they important? In R. Mc Donald, D.J. Hargreaves \& D. Miell (Eds.), Musical identities (pp. 1-20). Oxford: Oxford University Press.

Morawczynski, O. (2010). Examining the adoption, usage and outcomes of mobile money service: The case of 
M-PESA in Kenya (Unpublished doctoral thesis), the University of Edinburg, USA.

Palinkas, I. (2006). The development of the senses argumentum. Kossuth Egyetemi Kiado, Derecen, 2, 191-197.

Pallais, A. (2014). Inefficient hiring in entry-level labor markets. American Economic Review, 104, 3565-3599.

Rhodes, L. K. (2010). An apparent ugliness: Fashion and dressing poor (Unpublished MA thesis), RMIT Unuversity, Australia.

Rosinska, F.S. (2016). The comparison of a human being is a plant metaphor between English and Polish language. World Journal of Social Science, 3 (1) 15-21.

Scruton, R. (2005). Philosophy: Principles and problems. London: The University of Chicago Press.
Spivy, R. C. (2007). Analysis of ride quality of tractors semi-trailers (Unpublished MSC thesis), Clemson University, USA.

Steen, G., et al. (2010). A method for linguistic metaphor identification. Amsterdam: John Benjamins Publishing Company.

Simon, F., \& Wills, S. (2001). The Cambridge companion to pop and rock. Cambridge: Cambridge University Press.

Sullivan, S. (2013). Pop music. Encyclopedia of great popular song recording, 2, 101-103.

The Holy Bible (1982). New King James Version. Philadelphia: National Publishing Company.

Wheeler, M. (1994). Heaven, hell and the Victorians. Cambridge: Cambridge University Press. 